\title{
An Evaluation of the Effectiveness of Sports Sponsorship among Football Fans in Egypt
}

\author{
By Labiba Abdel-Naby Ibrahim*
}

Sports sponsorship in Egypt is growing. Thus, there is a critical need to have a solicitude in this area. One of the corporations aims is to increase its investments in sports. Nowadays; most of the corporations want to evaluate the influence of their communication to make better decisions. There is a lack of researches in this area in Egypt. This study examines theoretical relationships between key variables of sponsorship influence that include sponsor awareness, corporate image and future purchase intentions. Sports fans' involvement was also reviewed \& questionnaires were sent electronically via a social network (Facebook) to 107 football fans. The first section of the questionnaire was related to brand awareness items. The second section was about corporate image items. The third section was about purchase intention items. Finally, the last section was about the demographics of the respondents. Unaided recall tasks are considered to be more appropriate measures than recognition tasks because they require the respondent to retrieve the sponsor's name from memory rather than by recognizing their brand name from a list (Stotlar, 1993). Results suggested that sports fans' involvement had a direct positive effect on perceptions of corporate image; also, corporate image has a direct positive effect on purchase intentions, but there was no correlation between sports fans' involvement and intention to purchase the sponsor's product, and there was no correlation between sponsorship awareness and positive effect on corporate image. Finally, there was no correlation between sponsorship awareness and the effect on intentions to purchase a sponsor's products.

This paper is divided into nine sections; First is introduction,which contains the research objectives and statement of problem, Second is literature review which declared the relation among football fans and effects of sports sponsorship on (sponsorship awareness, corporate image and purchase intention) Third, a research model of the relationships among fan sports involvement, sponsor awareness, corporate image and purchase intention, Fourth, research methodology. Fifth, research hypothesis. Sixth, The demographic information. Seventh, The results. Eighth, Conclusion and discussion $\&$ Ninth limitations and future research.

${ }^{*}$ Lecturer, Faculty of Arts, Mass Communication Department, Helwan University, Egypt. 


\section{Introduction}

Sports is the area in which sponsorship has developed furthest. Depending on the year being studied and the country and definitions, the share of sports sponsorship within sponsorship as a whole lies approximately between 50\% and $70 \%$ of the total (Lagae 2005). Sponsorship is defined as a form to promote the brand associated with the concept of sports, entertainment, culture and society. It is one of the tools of the company's communication (Shimp, 2003). Sponsorship is the totality of market-orientated decision processes about the provision of money, services, know-how or in-kind support of corporations or organizations to individuals, groups or institutions from the area of sports, Culture, charity, ecology, education or broadcasting, in order to achieve specified corporate communication goals via the commercial and psychological potential associated with this activity (Tench and Yeomans, 2006). Sponsorship awareness, corporate image and purchase intention need to be measured in the context of sponsorship influence. Egyptian companies want to support sports events but there is only one study that tackled how these activities affect target markets and how to measure the sports sponsorship effectiveness (Ibrahim, 2011). Therefore, the main question of this research: are there any relationship between key variables (sponsor awareness, corporate image and future purchase intention) among football fans in Egypt?

The current study is aiming at investigating the factors of measuring the effectiveness of sports sponsorship. The objectives of the present study were specifically set as follows:

- To recognize how sponsorship works in the minds of consumers.

- To test the relationships between variables of sports sponsorship effectiveness (sponsor awareness, corporate image and future purchase intention).

- To offer a framework to those who are responsible for sponsorship in the Egyptian companies so that they can evaluate the activities of sport sponsorship via that.

\section{Literature Review}

\section{Sports Fans' Involvement}

The definitions and constructions that were used in these extant sports spectator involvement studies were basically derived from consumer involvement studies (Kim, AE, 2003). Consumer involvement is defined as 'the perceived interest in and personal importance of sports to an individual' (Shank \& Beasley, 1998). The importance of sports fans' involvement in predictions relating to their intention to purchase NFL teams' apparel was supported in (Sierra et. al., 2012) study, in which a sample of NFL fans at business school in the southwest U.S. were solicited as respondents and were asked to indicate their favorite NFL team and how long in terms of years they 
have felt this way; sports fans' involvement related to the term 'sport spectator' itself contains the meaning of behavioral contribution or behavioral aspect, Such as pending time, paying money to buy ticket, attending a game and analyzing information about sporting events is important for understanding sport spectator behaviors (Kim, AE., 2003).

Several studies have found that there was a relationship between people's involvement and perceptions; i.e., (Lee et. al. 2008) study in which the main purpose of it was to investigate how people's involvement with a celebrity influences their perceptions of tourism destinations; the level of celebrity involvement was positively related to destination familiarity and visitation intentions. (Tsuji, 2007) indicated that an increase in baseball involvement led to lesser likelihood of recall. Results indicated also that as viewers' involvement with baseball increased, recognition rates decreased for those brands with more exposure. The main objective of (Mohammadian \& Rahimipour, 2012) study was examining an integrated model of sports sponsorship in which team attachment is examined as an influential factor on brand image. The results show that team attachment has a direct and relatively strong impact on brand image of sponsors. This indicates that hardcore fans are more likely to have a positive brand image of sponsors.

Team attachment exhibited fairly strong total effects on both sponsor image and purchase intentions, which implies that highly attached fans are more likely to develop positive image about the sponsor and express willingness to buy its products (Tsiotsou \& Alexandris, 2009).

\section{Sponsorship Awareness}

Brand awareness refers to awareness at a specific point in time rather than knowledge of the brand; the term is used to refer to situational awareness, not absolute awareness (Holden, 1992).

In measuring brand awareness, unaided recall and aided recall (recognition) of sponsors are used (Ko et. al., 2008; Gilaninia and Reza, 2011). Unaided recall tasks are considered to be a more appropriate measure than recognition tasks because they require the respondent to retrieve the sponsor's name from memory rather by recognizing their brand name from list. An extension of exposure measurement is measurement of sponsorship awareness. In this type of test, a list of sponsored properties is presented to a sample of the target group, who are asked to name (aided or unaided) the sponsors of the property (Lagae, 2005). Tracking measures are designed to evaluate the awareness, familiarity and preferences engendered by sponsorship based on surveys (Belch, G. \& Belch, M., 2009); a review of sponsorship literature indicates that the primary objectives of corporate sponsorship are (a) increasing brand awareness (Pope, 1998); (b) enhancing corporate image (Yang et. al., 2008; Javalgi et. al., 1994) and (c) increasing sales (Crompton, 2004). Sponsorship awareness has a positive effect on corporate image 
Vol. 1, No. 2 Ibrahim: An Evaluation of the Effectiveness of Sports Sponsorship...

\section{Corporate Image}

Each company strives to attain a particular image with customers, stockholders and the general public. Sports is associated with a healthy lifestyle; this association can be good for the sponsor (Irwin et. al., 2002). Enhancement of corporate image is one of the most important communication objectives for corporate sponsors (Dolphin, 2003; Fullerton, 2007; Harris, 2005), but specific definitions of "image" and other sponsorship goals have been lacking. Similarly, though managers purport to measure the influence of their promotional activities (Javalgi et. al., 1994), previous research used to measure the effect of corporate image through consumers' attitude towards sponsors. (Kim, K., 2006; Stipp and Nicholas, 1996) found that the sponsor's image is related to viewers' evaluation and recall of the commercials; the researchers measured also attitudes toward Olympic sponsorship. Some researchers measured corporate image (Javalgi et. al., 1994; Crompton, 2004); others measured brand image (Phillip, 2000). Building brands through sponsorship is also investigated by (Cliffe, 2005). In an empirical study (Tsiotsou \& Konstantions, 2009) found that highly attached fans are more likely to develop positive image about their team's sponsor and consequently express positive intention to say good things and buy the sponsor's products.

\section{Purchase Intention}

Most studies concerned with prediction of human behavior from attitude have relied on the planned behavior theory (Zhao \& Othman, 2011). Some researchers studied the relationship between sport sponsorship and purchase intention. (Ngan et. al., 2011) found that team performance significantly influenced consumers' intention to purchase the sponsors' product. The premise is that highly attached fans are more likely to develop positive image for their team sponsor, exhibit higher intentions for purchasing and recommend the sponsor's products (Tsiotsou \& Konstantinos, 2009).

\section{Conceptual Background}

\section{Sports Sponsorship}

Sponsorship is a good tool that enhances the company's community involvement and portrays it as a good corporate citizen; as markets, they recognize that the initial task in getting consumers to purchase their products is to create awareness (Fullerton, 2007). Sport sponsorship acts first and foremost on cognitive goals, because sponsoring acts indirectly and implicitly, a brand also strives for effective goals (Lagea, 2005). 


\section{Effectiveness of Sponsorship}

Sponsorship is a worthwhile investment that would validate senior management decisions; they often commission evaluations in order to convince a partner to be involved in future events. The main motivation of a sponsorship evaluation is to measure ROI to determine if the return on their investment was worth it (O'reilly, 2007) S Sponsorship traditionally placed much emphasis on 'visibility' measurements; however, standard measures of brand awareness, recall and recognition are borrowed from conventional advertising research. These measures may be insufficient to measure sponsorship effectiveness in the digital age (Steyn, 2009).

\section{Research Model}

Evaluating sponsorship effectiveness based on single variables may not be sufficient due to the complex nature of the process of developing perceptions about sponsorship. Accordingly, to more fully recognition how sponsorship interact with sports fans, a researcher model (Ko et. al., 2008) was developed to delineate the proposed relationships among the four constructions (i.e., sports involvement, sponsor awareness, corporate image and future purchase intention) of sponsorship effectiveness.

Figure 1 illustrates the hypotheses that sports fan involvement directly affects awareness, image and purchase intention. Heightened levels of awareness and image predict a higher level of purchase intention. Corporate image is directly influenced by sponsor awareness. Each construct is discussed next, followed by pertinent research hypotheses.

Figure 1. Proposed RESEARCH MODEL of the Relationships among Fan Sports Involvement, Sponsor Awareness, Corporate Image and Purchase Intention (Ko et. al., 2008)

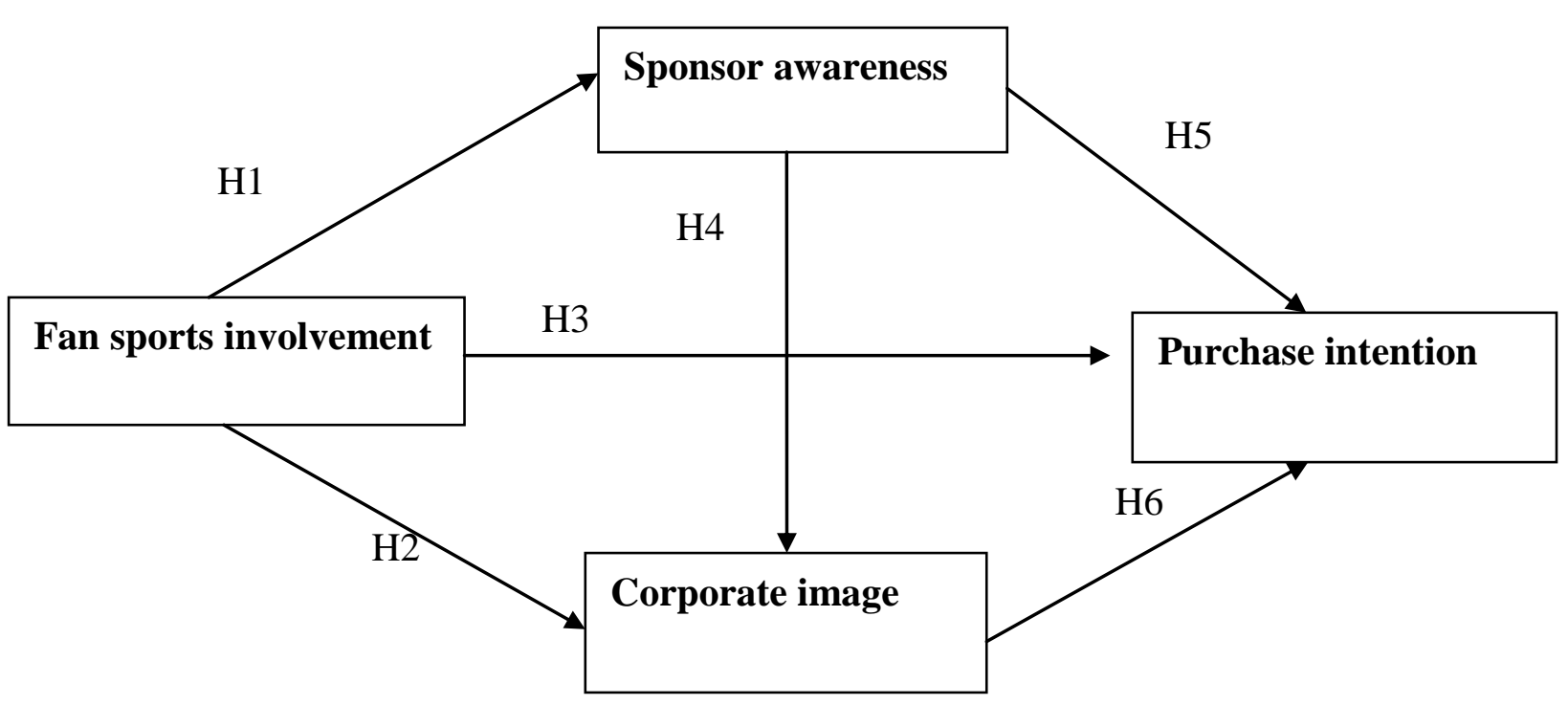


Vol. 1, No. $2 \quad$ Ibrahim: An Evaluation of the Effectiveness of Sports Sponsorship...

\section{Research Methodology}

\section{Measurement Instrument and Questionnaire Design}

For the purpose of this study, the researcher modified and used existing survey scales. The survey instrument included a series of questions related to the following five areas: Sports fan sponsorship, Sponsorship awareness, corporate image, Purchase intention and Demographic information.

Description of each sub-scale is presented in the next section. This study is based on snow sampling aged from 20 years \& older; the researcher depended on this kind of sampling technique to let participants obtain the sample by identifying other similar participants (Keyton, 2006).

The researcher used item -Likert scale to measure both of variables corporate image and purchase intention and used also sports fan involvement scale (SIS) to measure the interest of sports fans about the sport, It was important to use also unaided recall method to evaluate the sponsors advertisements impact on the fans memory by giving them a list of sponsors in varieties categories such as (fast food restaurants, airlines companies ,beverages companies ...etc)and then they asked for mentioning the sponsor's name of her/his favorite team .

107 respondents answered the questionnaire via Facebook; there were less responses because the researcher applied the study within (1st December 2012 and 1st January 2013), when most of the Egyptians were busy in the political events and referendum on the constitution; moreover, football activity had been frozen. In this study the researcher measured the interest of sports fans about the sport. Sports fan involvement is measured by (Shank and Beasley, 1998). Sports Involvement Scale (SIS) is used; the same scale has been used by (Ko et. al., 2008) study. The (SIS) includes 8 semantic items: ' $1 /$ Watching football matches is interesting 2/ I read about sport in newspapers 3/ My team's news attracts my attention on t.v. 4/ I like to attend my team's matches 5/ I watch all my team's matches on television 6/ I like to talk about my favorite team with my friends 7/ I follow my team's news in the newspapers and its results $8 /$ I follow my team's homepage on the internet'.

The researcher used unaided recall method to measure Brand Awareness; As recommended by several scholars (e.g. Turley \& Shannon, 2000). Recall tests can assess the ad's impact on the memory. Proponents of recall tests say the major concern is not the results themselves but how they are interpreted (Blech, G. \& Blech, M., 2009). Aided recall is where subjects are provided with the name of the company or product and then asked about the ads. On the other hand, unaided recall is where subjects are supplied only with a category and they must identify which ads they remember in that category. Unaided recall is the more stringent measure and often results in lower scores than aided recall (Berkman and Gilson, 1987).

The researcher adapted a 6-item scale to measure Corporate Image which was used by (Ko et. al. 2008 \& Javalgi et. al., 1994) which assesses six dimensions of corporate image: (1) sponsors have good product and services; (2) sponsors only want to make money; (3) sponsors target to support the 
football activity; (4) sponsors respond to consumer needs; (5) sponsors of my favorite team have a good reputation and credibility; (6) sponsors are good companies to work for. The format was a 3-point Likert scale ranging from 1(disagree) to 3 (agree).

The researcher measured Purchase Intention with a 3-item scale. Specific items include: (1) I am willing to try the products/services of team's sponsors; (2) I am willing to buy the products/services of the sponsors; (3) In the case of the company presenting new product/service, I will buy it.

Research Hypotheses

H1: sports fan involvement has a direct positive effect on sponsorship awareness.

$\mathrm{H} 2$ : sports fan involvement has a direct positive effect on perceptions of corporate image.

H3: sports fan involvement has a direct effect on intention to purchase a sponsor's product.

H4: sponsorship awareness has a direct positive effect on corporate image.

H5: sponsorship awareness has a direct effect on intention to purchase a sponsor's products.

H6: corporate image has a direct positive effect on intention to purchase.

\section{Demographic Information}

The last part of the survey asked the respondents to provide demographic information, which included gender, age, education, and income. In order to establish validity and reliability of the survey, the researcher conducted a field test and a pilot study prior to the actual survey. As a result of the experts' recommendations, a few modifications in the questionnaire were made. After the revised instruments were developed, the result of the reliability test of the questionnaire was 97\%.The sample of males is semi equal females (males $50.5 \%$ and females $49.5 \%$ ). The greatest percentage was the age from 20 to 30 years old $(80.4 \%)$ with a big difference from the other group (30-to more) $(19.6 \%)$. The higher educated had a great percentage $(78.5 \%)$, with a big difference compared to other two education groups (average $2.8 \%$ ), and posthigher education (18.7\%).regarding to the average of the sample monthly income the results were (less than 1000 L.E 15.0\%),(from 1000 L.E less than 3000 L.E 50.5\%)(from 3000 L.E less than 5000 L.E 24.3\%)(more than 5000 L.E $10.3 \%)$.

\section{Hypotheses Testing}

\section{H1: Sports Fan Involvement has a Direct Positive effect on Sponsorship Awareness.}

Pearson correlation between fan involvement and awareness ( $R=.211$, Sig.(2tailed=.029). This means that the main hypothesis of the study is accepted and that the correlation is significant at the 0.05 level (2-tailed). The results also indicate that increased fan involvement in a particular event will evoke more awareness of the team's sponsor. The results also support previous findings that 
highly involved consumers are more likely to be aware of sponsors (Ko et. al., 2008; Gilaninia and Reza, 2011). This finding is consistent with (Tsuji, 2007) study which proved that the effects of baseball involvement and team identification were found to affect awareness level.

This findings also consistent with (Ibrahim ,2011) study which proved that respondents have awareness about sponsorship activities specially football game the researcher suggest according to this finding that sponsor's brand is the main element in taking the buying decisions .a brand awareness is the main target of the sponsors and they use it to reinforce the loyalty to the company so sponsors can plan a strategies to support the brand awareness by organizing special events and sponsor another sports .the relationship between sports fan involvement and sponsorship awareness reflects varieties benefits not for sponsors only but for both sponsors and the consumers.

\section{H2: Sports Fan Involvement has a Direct Positive effect on Perceptions of Corporate Image}

Pearson correlation between fan involvement and perceptions of corporate image $(\mathrm{R}=.256$, Sig.(2-tailed=.008). The result supports previous findings that the highly involved the fans in sports, the highly positive image of the sponsors (Tsiotsou \& Alexandris, 2009; Ko et. al., 2008; Gilaninia and Reza, 2011) (Tsiotsou \& Alexandris, 2009) study proved that sponsor image was shown to be a mediator of the relationship between sport attachment and word-of-mouth. Also, It supports for the value of team attachment and sponsorship predicting behavioral sponsorship outcomes. This result also consistent with (Ibrahim, 2011) study which proved that sponsors used image methods to evaluate the return of sponsorship .image is an important indicator of sponsorship effectiveness, one of the ultimate goals of the sponsorship is to enhance positive image. The sponsorship is a new communication activity in Egypt, It helps companies to form an correlations in the customers' minds, So the sports fan can have loyalty towards sponsors services or products through it.

\section{H3: Sports Fan Involvement has a direct effect on Intention to Purchase a Sponsor's Product}

Pearson correlation between fan involvement and purchase a sponsor's product $(\mathrm{R}=.123$, Sig. (2-tailed $=206)$. This means there is no correlation between fan sports involvement and intention to purchase sponsor's product. This result may refer to the decrease of buying power of the respondents. This result is also not consistent with the previous research that mentioned the positive relationship between consumers' identification with nonprofit organizations and their intentions to purchase sponsors' products (Tsiotsou \& Alexandris, 2009) also the previous study posited that the relationship between fan identification and purchase intention is indirect ,so (Chin et. al., 2012)study attempts to gain a better understanding of the fan identification -purchase intention mechanism by empirically investigating the mediating role of sponsor credibility and attitude towards sponsor in this link. Based on the analysis of fan identification had significantly positive relationships with sponsor 
credibility, attitude towards international sponsors and purchase intention. This result is not supporting (Cornwell \&Coot 2003) study which proved that the effects of organizational prestige, years of participation, and primary motivation on sponsorship linked purchasing intent are mediated by organizational identification. The findings also not consistent with (Gilaninia and Reza, 2011) which confirmed that sport involvement has a direct positive effect on purchase intentions, the results of this study were interpreted with caution, for two reasons; First; Fans may be aware of corporate sponsors of sports event.

Second; Intention to purchase sponsors' products was determined in general. It is suggested that sponsors should consider football fans' behavior and their intentions. They should be interested in the fans because the latter are the final target of their sport marketing activities. Hypotheses 4 and 5 predicted that sponsorship awareness would have a direct positive effect on corporate image and the intention to purchase a sponsor's products.

\section{H4: Sponsorship Awareness has a Direct Positive effect on Corporate Image}

The test of hypothesis 4 confirmed that there were no correlation between sponsorship awareness and positive corporate image $(R=155$, Sig.(2-tailed $=.110$ ). The political events may have affected the mind of the sample, so they were not able to determine their perceptions toward sponsors. Previous studies have found a positive correlation between sponsorship awareness and corporate image (i.e., Woisetschlager, 2007; Nufer, 2009). It is suggested that sponsors should work on the development of consumers' awareness and do more efforts to increase it in fans' minds. The restoration of football activity may help them do that. the results also not consistent with ( Gilaninia and Reza, 2011) study which confirmed that fans that are aware of sponsors are likely to develop a positive image of the sponsoring companies .it is not consistent also with (Javalgi et. al., 1994) study which approved that respondents who were more aware of the sponsorship activities might also have been more aware of the companies in general ,so that their perceptions would have been built on a much wider body of knowledge .the researcher used unaided recall method to measure the respondents awareness of the sponsors ,may be this method not help them to determine their attitudes towards sponsors ,also there is (66.4\%)from total the respondents have a neutral attitudes towards sponsors image.

\section{H5: Sponsorship Awareness has a direct effect on Intention to Purchase a Sponsor's Products}

The test of hypothesis 5 confirmed no correlation between sponsorship awareness and intention to purchase a sponsor's product $(\mathrm{R}=.116$, Sig.(2-tailed $=.233$ ). This result is not consistent with the previous studies (Ko et. al. 2008). The respondents may have no intention to purchase a sponsor's product although they know the name of the sponsors as there were $61 \%$ have aware of sponsors of their favorite team. This means that hypotheses 4 and 5 are refused 
as there is no correlation between sponsor awareness and both corporate image and purchase intention of sponsor's products; therefore, it is proposed that marketers or public relations officials work on creating positive sponsor image, in order to increase sponsorship effectiveness. They should create programs and actions that will increase purchase intention. This can be done by promoting sponsorship efforts through different types of communication strategies (i.e., electronic mass media, internet (e.g., sports websites, the sponsors' website, social media and announcement in the stadiums). These actions can help in increasing positive corporate image and building purchase intention. The results also not consistent with (Gilaninia and Reza, 2011) study which approved that favorable purchase intentions are likely to occur for consumers who are aware of sponsors .

\section{H6: Corporate Image has a Direct Positive Effect on Intention to Purchase}

Hypothesis 6 predicted that corporate image has a direct positive effect on purchase intention $(\mathrm{R}=.377$, Sig.(2-tailed $=0.000)$. Correlation is significant at the 0.01 level (2-tailed). This result supports (Ko et. al., 2008) findings that customers with a more favorable image were more likely to purchase a sponsor's products. The significant impact of the image is a better predictor of sponsorship influence than sponsor awareness when we consider future purchase intention as an ultimate dependent variable of sponsorship. This result is consistent also with previous studies which proved that sponsor credibility and attitude towards sponsors partially mediate the fan identification -purchase link, by examining the effect on Asian fans' purchase intention when both the sponsoring firm and the sponsored sports team are Western (Chin et. al., 2012). The results also not consistent with ( Gilaninia and Reza, 2011) study which approved that favorable purchase intentions are likely to occur for consumers who are hold a positive image of sponsors. (O'reilly, 2007) investigated sponsorship evaluation practices ,the most common practice suggested by the experts is to measure sales or intent to purchase.

The model of this study has not achieved all its hypotheses; this result is not consistent with the review of literature (Ko et. al., 2008; Gilaninia and Reza, 2011). So, there is need to retest this model in several research environments.

Analysis of variance test (ANOVA) proved a significant difference between sponsorship awareness at the various education levels of respondents $\{(\mathrm{F}=4.194)(\mathrm{sig}=.018)\}$. To know the difference for whose interest, the least significant difference (LSD) was used to make a multiple comparison between these groups and it proved the following:

- There is a significant difference between the first group (higher education) and both average (mean difference $=-.85$, Sig=.010) and post higher education (mean difference $=-.65$, sig=.010).

- There is differences between age and purchase intention of sponsor's product $(\mathrm{T}$-test $=-3.266, \mathrm{p}=.001$ ). $\mathrm{T}$-test proved a significant differences for the respondent's age from (30 to 40 years old) [mean $=8.1905$, std. deviation $=.67964$ ], compared to the respondents from (20 to 30 years old ) [mean 
$=6.8721$, std. deviation $=1.81365]$. This result may refer to the buying power of the older respondents rather than the younger.

- There is difference between the respondents' education and sponsorship awareness ( $\mathrm{T}$-test $=-2.493, \mathrm{p}=.014)$ proved significant differences for postuniversity [mean $=2.80$, std. deviation $=.523$ ] compared to higher educated [mean $=2.18$, std. deviation $=1.073$ ]. This is an expected result as posteducated respondents have awareness about their favorite team sponsors than the less educated. There is also a difference between education and sports fan involvement. [T-test $=-3.755, \mathrm{p}=.000$ ] proved a significant differences for post-university [mean $=20.8000$, std. deviation=1.935] compared to higher educated [mean $=18.0000$, std. deviation $=3.22057$ ]. It is suggested that the researchers in their future study should focus on the relations between the demographics and variables of sponsorship effectiveness.

The statement on the sports fan involvement scale having greatest weight was 'watching football matches is interesting' $\{$ (weight $=92.30$, mean $=2.77$, std. deviation=.542) $\mathrm{\}}$. It is suggested that academics should examine the effects of watching football matches on recalling the names of sponsors.

On the other hand, the statement on the corporate image scale taking highest weight $=88.30$ was 'the sponsors of my favorite team have a good reputation and credibility', (mean $=2,65$, std. deviation= .584 ). According to this result, it is suggested that sponsors should consider the passion and loyalty of consumers when creating communication messages and they should be the target of most sports marketing activities.

'I'm willing to try products/services of team's sponsor.' The previous statement on purchase intention scale had greatest [weight $=86.00$, mean $=2.58$, std. deviation $=.695]$.

The results showed that there were no differences between the respondents' gender and variables of the study (sponsorship awareness, sports fan involvement, corporate image and purchase intention).

\section{Conclusion and Discussion}

The current research empirically examines theoretical relationships among the four constructs (i.e., sports fan involvement, sponsor awareness, corporate image and future purchase intention) of the sponsorship effectiveness.

Results of the regression analysis generally support only three hypothesized relationships. Hypotheses 1; predicted that sports fan involvement has a direct positive effect on sponsorship awareness $(\mathrm{R}=.211$, Sig.(2-tailed=.029). The results support previous findings (Ko et. al., 2008; Gilaninia and Reza, 2011; Tsuji, 2007;Ibrahim ,2011). Hypotheses 2; predicted that sports fan involvement has a direct positive effect on perceptions of corporate image $(\mathrm{R}=.256$, Sig.(2-tailed=.008). The result support previous findings (Tsiotsou \& Alexandris, 2009; Ko et. al., 2008; Gilaninia and Reza, 2011).Hypotheses 6; predicted that corporate image has a direct positive effect on intention to purchase $(\mathrm{R}=.377$, Sig. $(2$-tailed=0.000). The result support 
previous findings (Ko et. al., 2008; Chin et. al., 2012; Gilaninia \& Reza, 2011; O'reilly, 2007).

On the other side the results of analysis do not support three hypotheses relationships. Hypotheses 3 predicted that sports fan involvement has a direct effect on intention to purchase a sponsor's product $(\mathrm{R}=.123$, Sig. $(2$-tailed $=206)$

This result is not consistent with previous findings .the researcher suggests that sponsors should intensive concerns about the consumer behavior and improve the customer service also, may be it effects on the consumers specially after selling products, sponsors should apply new stratigies to raise brand awareness in fans minds. Hypotheses 4; predicted that sponsorship awareness has a direct positive effect on corporate image $(R=155$, Sig. $(2$-tailed $=.110)$. According to this result sponsors should plan for developing sponsorship appeals and confirm the importance of supporting sports activities ,the researcher found that this statement "sponsors only want to make money" was the fourth arrangement on Likert scale with percentage $78.00 \%$, std.deviation $=$ .764 ,this result consistent only with (Ibrahim ,2011) study which approved that the sports community in Egypt believed that sponsors target profit from this activity.Hypotheses 5; predicted that sponsorship awareness has a direct effect on intention to purchase a sponsor's products. $(\mathrm{R}=.116$, Sig. $(2$-tailed $=.233)$ this result is not consistent with previous research it is suggested according to this result that sponsors should enter a new markets, improve quality of services or products, sponsor another sports ,review their market segmentation stratigies and create a new methods to attract consumers whom have not any concerns about their services or products all the previous may help to effect the consumers behaviors.

\section{Limitations}

There are several limitations in this study. First, the sample was from football fans, using this category of sample limits our ability to generalize our findings. It will be necessary to conduct follow-up studies in other categories such as customers or football match viewers. Second, it is necessary to measure sponsorship effectiveness in various sports such as Olympic Games (volleyball, handball, etc). Third, to validate the model, it will be necessary to conduct follow-up studies in other sports sponsorship contexts. Inconsistent and a symmetric findings may indicate the importance of the organizational culture in studying sponsorship in Egypt, furthermore the sponsorship application is different compared to European or Asian environments ,so it is suggested that researchers in the field of marketing or public relations should consider the difference of the research environments and do a comparing studies between sports sponsorship in Egypt and other countries .it would be interesting to investigate if sponsors' brand ,attitude towards international sponsors ,etc,. Have an effect on the current framework .future research can consider these as control variables. 


\section{Bibliography}

Belch, George E. \& Michael A. Belch (2009). Advertising and Promotion integrated Marketing Communication Perspective $.8^{\text {th }}$ ed. New York: McGraw-Hill.

Berkman, H. W. \& C. Gilson (1987). Advertising . $2^{\text {nd }}$ ed. New York: Random House.

Chin, Michael, Hung Wang, Megha Jain, Julian Ming, Cheng Sung, George Kyaw \& Myo ung (2012). 'The purchasing impact of fan identification and sports sponsorship.' Marketing intelligence and planning, vol.30 (5)553-566 .

Cliffe, J. Simon \& Judy Motion (2005). 'Building contemporary brands: a sponsorship-based Strategy.' Journal of business research, vol. (58), issue 8:1068-1077.

Cornwell,T.Bettina \& Coot, Leonard V (2005).'Corporate sponsorship of a cause :the role of identification in purchase intent.' Journal of business research,vol.(58) 268-276.

Crompton, John L. (2004). 'Conceptualization and alternate operationalizations of the measurement of sponsorship effectiveness in sport.' Leisure studies, vol.23(3):267-281.

Dolphin, Richard R. (2003). 'Sponsorship: Perspective on its strategic role.' Corporate Communications :An international journal, vol. 8 (3):173-186.

Fullerton, Sam (2007). Sports Marketing. New York: McGraw-Hill.

Gilaninia, Shahram \& Mohamed Reza Abbaszadeh (2011). 'Assessing the constructs of sport sponsorship effectiveness and theoretical relationships between them among football fans in Iran.' Journal of basic and applied scientific research 1(7):606- 616.

Harris, Rebecca (2005).'When giving means taking: public relations, sponsorship, and morally marginal donors.' Public Relations Review, vol. (31):486-491.

Holden, Stephen J. S. (1992). 'Brand equity through brand awareness: measuring and managing brand retrieval.' Ph.D. diss., University of Florida.

Ibrahim, Labiba (2011). 'Evaluation of effectiveness of sports sponsorship in Egypt: An applied study.' Ph.D. diss., Helwan University.

Irwin, Richard L., William A. Sutton \& Larry M. McCarthey (2002). Sport Promotion and Sales Management. Illinois: Human Kinetics.

Javalgi, Rajshekhar G., Mark B. Traylor, Andrew C. Cross \& Edward Lampman (1994).'Awareness of Sponsorship and Corporate Image: An Empirical Investigation.' Journal of Advertising, vol. xxiii (4):47-58.

Keyton, Joann (2006). Communication research: asking questions, finding answers. $2^{\text {nd }}$ ed. New York: McGraw-Hill.

Kim, AE. Rang (2003). 'Development and validation of instruments for assessing sport spectator involvement and factors affecting sport spectator involvement.' Ph.D.diss., The University of New Mexico.

Kim, Kihan (2006). 'Managing Corporate brand Image through Sports Sponsorship: Impacts of Sponsorship on Building consumer perceptions of Corporate Ability and Social Responsibility. Ph.D. diss., The University of Texas at Austin.

Ko, Yong Jae, Kyoungtae Kim, Cathryn L. Claussen \& Tae Hee Kim (2008).'The effects of sport involvement, sponsor awareness and corporate image on intention to purchase sponsors' products.' International journal of sports marketing \& sponsorship, vol.9 (2):79-94.

Lagae, Wim (2005). Sport sponsorship and marketing communication: A European Perspective $.1^{\text {st }}$ ed. London: Pearson Education Limited. 
Vol. 1, No. $2 \quad$ Ibrahim: An Evaluation of the Effectiveness of Sports Sponsorship...

Lee, Soojin, David Scott \& Hyounggon Kim (2008). 'Celebrity fan involvement and destination perceptions.' Annual of tourism research, vol.35 (3):809-832.

Mohammadian, Mahmoud \& Negar Rahimipour (2012). 'Influential factors in customer's brand image of the sponsor.' International business and management, vol.5(1):43-51.

Ngan, Heidi M.K., Gerad P. Prendergast \& Alex S.L. Tsang (2011). 'Linking Sports Sponsorship with Purchase Intentions: Team Performance, Stars, and the Moderating Role of Team Identification.' European Journal of marketing, vol.(45)2:551-566.

Nufer, Gerd. (2009). 'Sponsoring the FIFA football world cup: The good, the bad and the surprising.' Journal of sponsorship, Vol. 2(3):241-249.

O'Reilly, Norman (2007). 'Sponsorship Evaluation.' Ph.D. diss., Carleton University.

Philip, Roy Donald (2000). 'An examination of the influence of perceived brand-event congruence on consumer responses to event sponsorship.' Ph.D.diss., The University of Memphis.

Pope, Nigel (1998). 'Consumption Values, Sponsorship Awareness, Brand and Product Use.' Journal of product \& brand management, vol.7 (2):124-136. available at http:www.emeraledinsight.com.

Shank, M.d. \& F.M. Beasley (1998). 'Fan or fanatic: refining a measure of sports involvement.' Journal of Sport Behaviour (21)4:435-443.

Shimp, Terence A. (2003). Advertising, Promotion \& Supplemental Aspects of Integrated Marketing Communications. $6^{\text {th }}$ ed. CT: Thomson Learning.

Sierra, Jeremy J., Harry A. Taute \& Roberts Heiser (2012). 'Explaining NFL fans' purchase intentions for revered and reviled teams: A dual-process perspective.' journal of retailing and consumer services (19) 332-342.

Steyn, Peter G. (2009). 'Online Recommendation As the Ultimate Yardstick to measure sponsorship Effectiveness.' Journal of Sponsorship, vol. (2)4:316-329.

Stipp, Horst \& Nicholas P. Schiavone (1996). 'Modeling The Impact of Olympic Sponsorship On Corporate Image.' Journal of Advertising and Research: 22-28.

Stotlar, D.K. (1993). 'Sponsorship and the Olympic Games.' Sport marketing quarterly 1(1):35-43 .

Tench, Raleph \& Liz Yeomans (2006). Exploring Public Relations. $1^{\text {st }}$ ed. London:Pearson education limited.

Tsiotsou, Rodoula \& Konstantinos Alexandris (2009). 'Delineating the outcomes of sponsorship: sponsor image, word of mouth and purchase intentions.' International journal of retail and distribution management, vol.3 (4):358-369.

Tsuji, Yosuke (2007). 'Brand awareness of virtual advertising in sport.' Ph.D.diss., Texas A\&M University.

Turley, L. W. \& J. Richard Shannon (2000). 'The impact and effectiveness of

Advertisements in a sports arena.' Journal of services marketing, vol. (14)4:323-336.

Woisetschläger, David M. (2007). 'Team-Sponsorship in the Formula One - Does it affect Brand perception? An Empirical Assessment in the German Car market.' Advances in Consumer Research, Vol. 34:616-623.

Yang, Xinquan Sheena, Robert Sparks \& Ming Li (2008). 'Sports sponsorship as strategic investment in China: perceived risks and benefits by corporate sponsors prior to Beijing 2008 Olympics.' International journal of sports marketing \& sponsorship,vol.10 (1):63-78.

Zhao, Wenjie \& Md Nor Othman (2011). 'Predicting and explaining complaint intention and behaviour of Malaysian Consumers: An application of the planned behaviour theory.' Vol. (21):229-252. 